\title{
Production parameters and forage loss of oat and rye grass pastures managed with beef heifers fed diets with energy supplementation
}

\section{Luiz Angelo Damian Pizzuti ${ }^{1}$, Dari Celestino Alves Filho', Ivan Luiz Brondani ${ }^{1}$, Leandro da Silva Freitas ${ }^{1}$, Patrícia Alessandra Meneguzzi Metz ${ }^{1}$, Álisson Marian Callegaro ${ }^{1}$, Rangel Fernandes Pacheco ${ }^{1}$, Lucas Braido Pereira ${ }^{1}$}

\begin{abstract}
${ }^{1}$ Departamento de Zootecnia - Universidade Federal de Santa Maria.
ABSTRACT - Production parameters of intercropped pastures of oat and rye grass managed with beef heifers supplemented with brown rice meal and/or protected fat were evaluated. Twenty-eight Charolais $\times$ Nellore crossbred heifers at initial average age of 18 months and initial average live weight of $274.9 \mathrm{~kg}$ were utilized in the experiment. Animals were kept on oat + rye grass pastures and distributed in the following treatments: no-supplementation (NS): heifers kept only in pastures; Megalac (MEG): supplementation with protected fat; brown rice meal (BRM): supplementation with BRM; BRM + MEG: supplementation with BRM plus protected fat. The greater participation of oat leaf was from July 5th to August 10th, 2009 and of rye grass, from August 30th to September 26 th, 2009. The crude protein content increased until the 55 th day $(225.1 \mathrm{~g} / \mathrm{kg}$ ). Pasture total digestible nutrients presented a cubic behavior, with an average of $722.0 \mathrm{~g} / \mathrm{kg}$. The highest supply of leaf blades, $5.17 \mathrm{~kg}$ of dry matter $/ 100 \mathrm{~kg}$ of live weight, was found in the second period. Pasture intake increased throughout the periods. Forage mass and support capacity of the animal did not differ between treatments, presenting means of $1245.02 \mathrm{~kg}$ of dry matter/ha and $882 \mathrm{~kg}$ of live weight/ha, respectively. Stoking rate, forage loss and pasture intake were not affected by the treatments. Supplementation of beef heifers with rice meal and/or protected fat did not change production parameters of oat + rye grass pastures or pasture intake. Increase in daily accumulation rate of dry matter and supporting capacity of the animals increases forage losses.
\end{abstract}

Key Words: crude protein, forage loss, forage mass, intake, leaf blade offer

\section{Introduction}

Knowledge of variables influencing the beef cattle production system, be it extensive, semi-intensive or intensive is determining for the final desired objective to be reached within thresholds economically consistent with the response targeted. The planning of livestock activity based on pasture implies knowing the distribution pattern of forage production over growth season, estimating the expected forage productivity and defining the supporting capacity of the animal in function of the individual weight gain designed for each category (Freitas et al., 2005a). The understanding and the correct application of technology guiding forage production take fundamental role in the survival of the production systems (Roso et al., 1999), in which more intensive systems are those in which forage is the main component of the diet, but with the addition of several forms of animal supplementation (Rocha et al., 2004).

Utilizing supplements alone or in mixtures may change pasture management due to the effect provided to the animals, known as substitutive, additive or additive/ substitutive effect. The occurrence of such effects will be conditioned to the level and to the types of supplements used, which almost always cause an effect mainly concerning the supporting capacity of the animal as well as forage selectivity by the animal, which may be influenced so as to change the productive response of the pasture.

When evaluating growth of beef heifers grazing black oat + rye grass, Pilau et al. (2004) found that the supply of $15 \mathrm{~g}$ of wheat meal per $\mathrm{kg}$ of live weight provided a greater supporting capacity of the animal. In another study, supplementation with $10 \mathrm{~g}$ of ground sorghum per kilogram of live weight promoted greater mass of leaf blades in oat + rye grass pastures and an increment in the supporting capacity of the animal (Rocha et al., 2004). Pasture supplementation may also affect weight gain and stoking rate in a positive manner, allowing that a greater number of females be ready for matting simultaneously (Pötter, 2008); however, the understanding of pasture response when certain supplements are supplied to the animals 
is very important to comprehend the animal interface, plant and management. In addition to those factors, some supplements such as protected fat tend to benefit other animal interests. According to Funston (2004), the use of lipid supplements may have a positive effect on reproduction of beef cattle regardless of the input energy. It has been demonstrated that the use of lipid supplements positively affects important reproduction functions in many tissues, including the hypothalamus, anterior hypophysis, ovary and uterus.

Thus, the objective of this study was to evaluate production parameters and forage losses of pastures with intercropping of oat and rye grass managed with beef heifers supplemented with brown rice meal and/or protected fat.

\section{Material and Methods}

The experiment was carried out in the Beef Cattle Laboratory in the Animal Science Department of Universidade Federal de Santa Maria. This area is located in Central Depression of Rio Grande do Sul, at $95 \mathrm{~m}$ of altitude, $29^{\circ} 43^{\prime}$ South latitude and $53^{\circ} 42^{\prime}$ West longitude. The soil in the experimental area belongs to São Pedro mapping unit and is classified as paleaudalf (Embrapa, 1999), presenting a slightly undulating relief, with deep, well drained and naturally acid soils with sandy superficial texture. The climate in the region is Cfa (subtropical humid), according to the Köppen classification, with an annual average rainfall of $1769 \mathrm{~mm}$, annual mean temperature of $19.2^{\circ} \mathrm{C}$, with minimum mean temperature of $9.3{ }^{\circ} \mathrm{C}$ in June and maximum mean temperature of $24.7^{\circ} \mathrm{C}$ in January (Table 1), insolation of 2212 annual hours and relative air humidity of $82 \%$ (Moreno, 1961).

The experimental area corresponded to 16.3 ha, with 11.7 ha divided in 12 paddocks with a variable area where control animals were managed and 4.6 ha where the regulating animals stayed. Pasture implementation took place on April 1st, 2009 with a broadcast sowing of $31.2 \mathrm{~kg} / \mathrm{ha}$ of rye grass (Lolium multiflorum Lam.) seeds based on $100 \%$ of cultural value and on April 2nd, 3rd and 4th, row sowing of $77.4 \mathrm{~kg} / \mathrm{ha}$ of black oat (Avena strigosa Schreb.) seeds based on $100 \%$ of cultural value was performed. Base fertilization used $141 \mathrm{~kg} /$ ha of 5-20-20 NPK fertilizer. Cover fertilization was done at four moments: June 4th, 2009 - $47 \mathrm{~kg} /$ ha urea; June 16th, 2009 - $124 \mathrm{~kg} / \mathrm{ha} 5-20-20$ NPK fertilizer; September 11th, 2009 - $77 \mathrm{~kg} / \mathrm{ha}$ urea; August 22nd, 2009 - $38.5 \mathrm{~kg} / \mathrm{ha}$ urea.

Pastures took 70 days to be established, and then the animals were placed on them. The last 15 days before the beginning of the experimental period were for adaptation of the animals to the supplement and to the management. Experimental period totalized 112 days, from July 5th, 2009 to October 24th, 2009, divided into four 28-day periods. Twenty-eight Charolais $\times$ Nellore crossbred heifers at initial average age of 18 months and initial average live weight of $274.9 \mathrm{~kg}$ were distributed in the following treatments: no-supplementation (NS): heifers kept on oat + rye grass pastures only; Megalac (MEG): heifers kept on oat + rye grass pastures fed $3 \%$ of protect fat under estimate of total dry matter intake, set at $30 \mathrm{~g} / \mathrm{kg}$ of live weight (LW); brown rice meal $(\mathrm{BRM})$ : heifers kept on oat + rye grass pastures fed brown rice meal at the level of $8 \mathrm{~g}$ per $\mathrm{kg}$ of live weight; brown rice meal + Megalac $(B R M+M E G)$ : heifers kept on oat + rye grass pastures fed brown rice meal at the level of $8 \mathrm{~g} / \mathrm{kg}$ of live weight plus $3 \%$ of protected fat under estimate of total dry matter set at $30 \mathrm{~g} / \mathrm{kg}$ of live weight.

Each treatment consisted of three replicates per area, with a variable number of animals within the replicates; two paddocks with two heifers each one and a paddock with three heifers.

Forage mass was determined by the double-sampling technique (Wilm et al., 1944), at the beginning of the grazing period and then every 14 days. Five cuts of $0.25 \mathrm{~m}^{2}$ were performed at the ground level in each replicate and 20 visual estimates were also done. A sample was taken from each cut performed in the replicate for a composite sample.

Table 1 - Means of maximum temperature (Max T), minimum temperature (Min T), mean temperature $($ Mean $\mathrm{T})$, rainfall $(\mathrm{mm})$ and insolation (hours) observed from April to October 2009 (M) and in 30 years of observations (Y)

\begin{tabular}{|c|c|c|c|c|c|c|c|c|c|c|}
\hline \multirow{2}{*}{ Month } & \multicolumn{2}{|c|}{$\operatorname{Max} \mathrm{T},{ }^{\circ} \mathrm{C}$} & \multicolumn{2}{|c|}{$\operatorname{Min} \mathrm{T},{ }^{\circ} \mathrm{C}$} & \multicolumn{2}{|c|}{ Mean $\mathrm{T},{ }^{\circ} \mathrm{C}$} & \multicolumn{2}{|c|}{ Rainfall, mm } & \multicolumn{2}{|c|}{ Insol. hours } \\
\hline & Y & M & $\mathrm{Y}$ & M & Y & M & Y & M & Y & M \\
\hline April & 25.0 & 27.3 & 14.5 & 14.0 & 18.8 & 19.2 & 182.2 & 25.6 & 168.7 & 218.9 \\
\hline May & 22.1 & 23.8 & 11.8 & 12.1 & 16.0 & 16.6 & 153.0 & 96.5 & 151.3 & 153.6 \\
\hline June & 19.2 & 18.5 & 9.3 & 7.3 & 12.9 & 11.9 & 109.2 & 76.8 & 125.0 & 158.1 \\
\hline July & 19.6 & 17.2 & 9.5 & 6.3 & 13.5 & 10.8 & 105.0 & 91.4 & 133.1 & 152.7 \\
\hline August & 20.3 & 23.1 & 10.4 & 11.4 & 14.6 & 16.4 & 97.0 & 164.5 & 141.4 & 109.9 \\
\hline September & 21.9 & 20.8 & 11.3 & 12.5 & 16.2 & 16.1 & 108.4 & 345.6 & 160.7 & 123.1 \\
\hline October & 24.8 & 25.3 & 13.5 & 13.4 & 18.8 & 18.9 & 145.0 & 108.7 & 206.8 & 220.9 \\
\hline
\end{tabular}


Forage from the composite sample was homogenized and divided in two sub-samples, one for the determination of dry matter (DM) content and the other for manual separation of plant components of the pasture in leaf of the oat, stem of the oat, leaf of the rye grass, stem of rye grass, dead material and other species.

A continuous grazing method with variable stocking rate was adopted, using the "Put and take" technique (Mott \& Lucas, 1952). Forage mass was pre-determined at $1200 \mathrm{~kg} \mathrm{DM} / \mathrm{ha}$. Regulating animals were used whenever necessary. Those animals were kept in an area attached to the experimental area with oat + rye grass pasture for adjustment of forage availability. For the adequation of the animal supporting capacity and intended forage mass, a forage disappearance rate of $45 \mathrm{~g} / \mathrm{kg}$ of DM (30 g of intake $+15 \mathrm{~g}$ of forage loss) was considered. Thus: adjusted supporting capacity $=$ (daily accumulation rate + (actual forage mass - forage mass desired)/number of days $* 100 /$ forage disappearance rate.

The estimation of daily accumulation rate of pasture dry matter was performed every 28 days by using three cages of grazing exclusion per paddock according to the methodology described by Klingmann et al. (1943). Dry matter accumulation rate per period was estimated through the equation described by Campbell (1966):

$$
\mathrm{Tj}=\frac{\mathrm{Gi}-\mathrm{Fg}(\mathrm{i}-1)}{\mathrm{n}}
$$

In which: $\mathrm{Tj}=$ daily $\mathrm{DM}$ accumulation rate/ha, in period $\mathrm{j} ; \mathrm{Gi}=$ average $\mathrm{DM}$ amount/ha of the three cages in evaluation i; $\mathrm{Fg}=$ average of the amount of $\mathrm{DM} / \mathrm{ha}$ at the three points at evaluation $\mathrm{i}-1 ; \mathrm{n}=$ number of days in the period. Total dry matter production was calculated by the sum of the production in the periods (daily accumulation rate $\times$ number of days) added by initial forage mass.

Forage loss was determined by the methodology proposed by Hillesheim (1987), in which nine sampling points were defined in each paddock, in three transects by using wood poles buried in the soil. Poles were approximately $10 \mathrm{~cm}$ above ground and every 28 days, $0.0625 \mathrm{~m}^{2}$ squares were placed between them for collection of forage regarded as non-usable by the animals (senescent, dead material or material damaged by trampling and defecation). Samples were taken to oven for being weighed and dried. The amount of DM obtained in the total collected area $\left(0.0625 \mathrm{~m}^{2} \times 9\right.$ sampling points $)$ was extrapolated by one hectare, so forage mass was determined per period and per treatment in $\mathrm{kg} /$ day/ha of DM. Forage loss was obtained in $\%$ of live weight by dividing forage loss by supporting capacity of the animal. For the calculation of the estimate of DM intake per treatment and period, final forage mass of the period and forage loss occurring over the period were subtracted from total production of DM/ha in the period. Dry matter intake was obtained in $\mathrm{g} / \mathrm{kg}$ of live weight for each period by dividing the estimated intake of $\mathrm{DM} /$ ha by the animal supporting capacity in the period.

Supporting capacity of the animal per period was calculated by summing average weight of control animals (Pt), added by weight of regulating animals (Pr), multiplied by number of days that the latter ones stayed on pasture (D) and divided by the number of days in the period (NDP). Supporting capacity of the animal was expressed in $\mathrm{kg}$ of LW/ha according to the following formula:

Supporting

$$
\text { capacity of the animal }=\mathrm{Pt}+\frac{(\operatorname{Pr} 1 \times \mathrm{D} 1)}{\mathrm{NDP}}+\frac{(\mathrm{Pr} 2 \times \mathrm{D} 2)}{\mathrm{NDP}} \cdots
$$

From the values of forage mass, pasture accumulation rate and supporting capacity of the animal, forage supply, in $\mathrm{kg}$ of $\mathrm{DM} / 100 \mathrm{~kg}$ of $\mathrm{LW}$, was determined through the formula: $\mathrm{FS}=((((\mathrm{iMF}+\mathrm{fMF}) / 2) /$ no. of days $)+\mathrm{DAR}) /$ $\mathrm{SC}^{*} 100$, in which: $\mathrm{FS}=$ forage supply in the period; iMF = initial forage mass in the period; $\mathrm{fMF}=$ final forage mass in the period; $\mathrm{DAR}=$ daily accumulation rate of $\mathrm{DM}$ in the period; $\mathrm{SC}=$ supporting capacity of the animal in the period. Leaf blade supply was obtained by multiplying the percentage of leaf blade by forage supply.

For sampling of forage consumed by the heifers, grazing simulations were carried out in each experimental period, in which two trained evaluators collected approximately $0.4 \mathrm{~kg}$ of forage material similar to that collected by the animals after 15 minutes of observing their ingestive behavior (Euclides et al., 1992). Samples were pre-dried in forced circulation oven at $55^{\circ} \mathrm{C}$, for 72 hours, until constant weight, when they were ground in Willey-type mill with $1 \mathrm{~mm}$ mesh sieve.

The dry matter content was determined by drying in an oven at $105{ }^{\circ} \mathrm{C}$ until constant weight; ash was determined by calcination in muffle at $550{ }^{\circ} \mathrm{C}$ for 4 hours. The organic matter content was calculated by reducing the value found in dry matter by the value found for ashes. Total nitrogen content was determined by the method of Kjeldahl (AOAC, 1995). The content of ether extract was determined after treating the samples with ether, in a reflow system at $180^{\circ} \mathrm{C}$ for 2 hours (AOAC, 1995). Contents of neutral detergent fiber, acid detergent fiber, acid detergent lignin and nonstructural carbohydrates were determined according to Van Soest et al. (1991). Contents of neutral detergent insoluble nitrogen and acid detergent insoluble nitrogen were determined according to Licitra et al. (1996). 
Total digestible nutrients (TDN) were calculated from chemical composition of feeds through equation of Weiss et al. (1992), as in the following description:

$\mathrm{TDN}=\operatorname{digNFC}+\operatorname{digCP}+(\operatorname{digEE} \times 2.25)+\operatorname{digNDF}-7$

In which:

$\operatorname{digNFC}=0.98 *(100-(\mathrm{NDFap}+\mathrm{CP}+\mathrm{EE}+\mathrm{Ash})) ;$

forage $\operatorname{digCP}=\mathrm{CP} * \operatorname{Exp}(-1.2 *((\mathrm{ADIN} * 6.25) / \mathrm{CP}))$;

concentrate $\operatorname{digCP}=(1-(0.4 *((\mathrm{ADIN} * 6.25) / \mathrm{CP}))) * \mathrm{CP}$;

$\operatorname{dig} \mathrm{EE}=(\mathrm{EE}-1)$;

$\operatorname{digNDF}=0.75 *($ NDFap-ADL $) *\left(1-(\text { ADL/NDFap })^{0.667}\right)$

$\operatorname{digNFC}=$ digestible non-fibrous carbohydrates; forage $\operatorname{digCP}=$ digestible crude protein of the forage; concentrate $\operatorname{digCP}=$ digestible crude protein of the concentrate; $\operatorname{digEE}=$ digestible ether extract; $\operatorname{digNDF}=$ digestible neutral detergent fiber; $\mathrm{ADL}=$ acid detergent lignin; $\mathrm{ADIN}=$ acid detergent insoluble nitrogen; NDFap $=$ neutral detergent fiber corrected for ash and protein; and $\mathrm{CP}=$ crude protein. The subtracted value 7 refers to the adjustment factor for the metabolic fecal TDN.

The experimental design was completely randomized with three replicates per area in a $4 \times 4$ factorial arrangement (four treatments $\times$ four periods). The variables were tested for normality by using the Shapiro-Wilk test. Data were submitted to analyses of variance and the $\mathrm{F}$ test at the level of $5 \%$ of significance by using PROC MIXED, and AIC was used as the information criterion for choosing the best covariance structure, and when differences between means were found, they were compared by Student's t test.

The mathematical model used in the analyses of variance was the following:

$$
\mathrm{Y}_{\mathrm{ijk}}=\mu+\mathrm{T}_{\mathrm{i}}+\mathrm{R}_{\mathrm{k}}\left(\mathrm{T}_{\mathrm{i}}\right)+\mathrm{P}_{\mathrm{j}}+(\mathrm{TP})_{\mathrm{ij}}+\mathrm{e}_{\mathrm{ijk}}
$$

In which: $\mathrm{Y}_{\mathrm{ijk}}=$ dependent variables; $\mu=$ mean of all observations; $T_{i}=$ effect of the $i$-th feeding treatment; $R_{k}$ $\left(\mathrm{T}_{\mathrm{i}}\right)=$ effect of the k-th repetition within the $\mathrm{i}$-th treatment (error a); $P_{j}=$ effect of the $j$-th period; $(T P)_{i j}$, = interaction between the $\mathrm{i}$-th treatment and the $\mathrm{j}$-th period; and $\mathrm{e}_{\mathrm{ijk}}=$ total experimental error (error b).

Regression test, Lack-of-fit test and test of correlation were carried out at the level of 5\% of significance. Data analyses were done by using statistical package SAS (Statistical Analysis System, version 8.01).

\section{Results and Discussion}

The average rainfall observed in the months of pasture establishment (April and May) was extremely low, especially in April, corresponding to only $14.5 \%$ of the average observed in 30 years, with all rainfall occurring in only one day (Table 1).
The low rainfall at the moment of crop establishment delayed initial development of the plants, especially for oats, due to the lack of humidity, contributing to prorogation of the animal entry into the pastures, occurring after 70 days of pasture establishment. However, oat has the capacity of withstanding long drought periods, recovering after rainfall (Baier et al., 1989). Pasture period for oat + rye grass mixture usually takes place between 45 to 60 days (Roso et al., 2000; Frizzo et al., 2003; Pilau et al., 2005b). Another untypical factor found was rainfall above average from August to September, 69.6 and 218.8\%, respectively, concomitant to insolation for those two months, $27 \%$ lower than the average. When insolation is reduced, the energy absorbed by photosystems of chloroplasts will be reduced, so lower amounts of electrons are carried, thus reducing energy production from photosynthesis and the development of plants as a consequence (Taiz \& Zeiger, 2009).

There was no interaction $(\mathrm{P}>0.05)$ between treatment and period for variables of plant composition, which presented distinct behavior over periods, and participation of leaves of oats (Figure 1) reduced as pasture development stage advanced, and its contribution to leaf blade mass was null in the last days of pasture use. The reduced participation of oat leaves in the initial period of grazing may be explained as a function of the low rainfall (Table 1) which occurred in the beginning of pasture establishment, although there was a great contribution by oat leaves in June and July in function of production concentration, which was around 60\% (Baier et al., 1989).

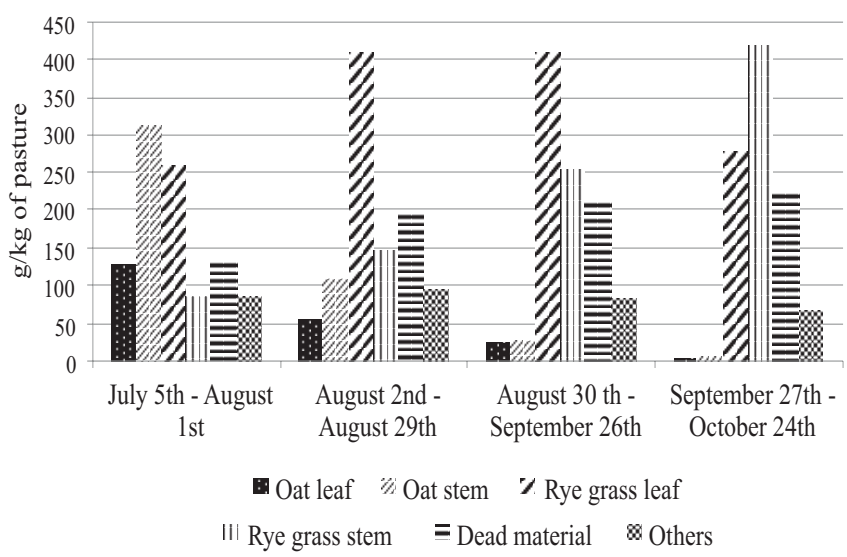

Oat leaf $=153.8042-1.4591 *$ Day $\left(\mathrm{R}^{2}=0.83 ; \mathrm{CV}=41.12 \% ; \mathrm{P}<0.0001\right)$ Oat stem $=364.2167-3.5701 *$ Day $\left(\mathrm{R}^{2}=0.80 ; \mathrm{CV}=49.73 \% \mathrm{P}<0.0001\right)$ Rye grass leaf $=-28.5396+12.8493 *$ Day- $0.0904 *$ Days $^{2}\left(R^{2}=0.68 ; C V=14.95 \%\right.$; $\mathrm{P}<0.0001)$.

Rye grass stem $=-51.5208+3.9811 *$ Day $\left(\mathrm{R}^{2}=0.90 ; \mathrm{CV}=18.17 \% ; \mathrm{P}<0.0001\right)$. Dead material $=117.4458+1.0837 *$ Day $\left(\mathrm{R}^{2}=0.35 ; \mathrm{CV}=24.52 \% ; \mathrm{P}<0.0001\right)$ Others $=79.4(\mathrm{P}>0.05)$

$\mathrm{CV}$ - coefficient of variation.

Figure 1 - Plant composition of oat + rye grass pastures over grazing period. 
When climate conditions were favorable, the component oat leaf contributed with $439.0 \mathrm{~g} / \mathrm{kg}$ of available forage in a study carried out by Frizzo et al. (2003) in the same area. The importance of using intercropping of oat + rye grass gets clear when oat leaves are reduced in the forage mass and there is an increase in rye grass leaves starting from late July (Figure 1), remaining constant during August and September, from which participation of stems of rye grass gains expressivity.

Pasture dead material presented an increasing behavior (Figure 1) due to the use of two forage species with distinct growth, black oat, which presents growth faster than the one of rye grass, and therefore it enters in the reproductive stage earlier than the other, whereas rye grass tends to present a slower growth. However, its grazing is longer, (Fonseca, 1997), thus increasing participation of dead material throughout grazing.

The chemical composition of grazing pasture simulation apprehended by heifers did not present interaction between treatment and period and it did not differ $(\mathrm{P}>0.05)$ between treatments (Table 2).

Pasture dry matter (DM) ranged during the oat + rye grass grazing period, in which the leaf of rye grass was the main factor for this behavior, presenting a correlation of -0.55 $(\mathrm{P}<0.0001)$. Pasture crude protein $(\mathrm{CP})$ increased until day 55 , and then it decreased until final grazing period. The leaf/stem ratio (Table 3) presented an evolution close to $\mathrm{CP}$, with maximum participation on the 66th day and when the variables were correlated, the resulting coefficient was $0.41(\mathrm{P}=0.0037)$. The $\mathrm{CP}$ content found in all periods in analyses of grazing simulation is above that recommended by the NRC (1996), $126 \mathrm{~g} / \mathrm{kg}$ of CP, for beef heifers to gain approximately $1.1 \mathrm{~kg}$. Although the $\mathrm{CP}$ requirement was met in all periods, it is important to highlight that there are some variations over the grazing cycle, once the use of average content to infer the gain of the grazing heifers may induce to errors which will influence animal performance, especially if the pasture does not present a high content of $\mathrm{CP}$, like temperate grasses.

The content of totaldigestiblenutrients(TDN) presented a cubic behavior $\left(\mathrm{Y}=829.7598-6.1384 * \mathrm{Day}+0.1026 * \mathrm{Day}^{2}\right.$ $0.0005121 *$ Day $^{3} \mathrm{R}^{2}=0.17 ; \mathrm{CV}=2.96 \% \mathrm{P}=0.0212$ ), which was higher than $70 \%$ in all periods of the pasture cycle. High content of pasture TDN is particularly associated with the amount of ether extract and the low neutral detergent fiber obtained in samples of grazing simulations, which are in agreement with data reported in the literature (Silveira et al., 2006; Rodrigues et al., 2002).

There was no interaction $(\mathrm{P}>0.05)$ between treatment and period for the variables of pasture response (Table 3 ). Forage mass did not present a significant alteration over the periods, staying close to the target forage mass of $1200 \mathrm{~kg}$ of $\mathrm{DM} / \mathrm{ha}$, so forage offer was not altered either. To avoid reduction of pasture intake, with a consequence compromising of animal performance, pasture shall be managed keeping a minimum availability of $1200 \mathrm{~kg} / \mathrm{ha} / \mathrm{DM}$ (Moraes, 1991).

Besides not compromising animal performance, the lower maintenance of forage availability by using supplementation enables increase in the supporting capacity of the animal (Pilau et al., 2005a), which is very important for obtaining increase in the productive response per area, mainly when the animal category is beef heifers for reposition.

Table 2 - Means and regression equations of chemical analyses of samples from grazing simulation in different periods

\begin{tabular}{|c|c|c|c|c|c|}
\hline \multirow[b]{2}{*}{ Variable, $\mathrm{g} / \mathrm{kg}$} & \multicolumn{4}{|c|}{ Period } & \multirow[b]{2}{*}{ Mean } \\
\hline & $\begin{array}{l}\text { July 5th - } \\
\text { August 1st }\end{array}$ & $\begin{array}{l}\text { August 2nd - } \\
\text { August 29th }\end{array}$ & $\begin{array}{l}\text { August 30th - } \\
\text { September 26th }\end{array}$ & $\begin{array}{l}\text { September 27th - } \\
\text { October 24th }\end{array}$ & \\
\hline Dry matter ${ }^{1}$ & 188.4 & 176.7 & 168.2 & 202.7 & 184.4 \\
\hline Organic matter ${ }^{2}$ & 880.6 & 877.7 & 895.4 & 896.4 & 887.3 \\
\hline Crude protein ${ }^{3}$ & 212.9 & 219.2 & 215.5 & 158.5 & 201.1 \\
\hline Neutral detergent fiber ${ }^{4}$ & 379.1 & 397.9 & 432.4 & 420.9 & 407.3 \\
\hline Acid detergent fiber ${ }_{a}^{5}$ & 206.7 & 237.0 & 242.7 & 247.9 & 233.6 \\
\hline Ether extract ${ }^{6}$ & 52.1 & 56.8 & 57.9 & 41.0 & 51.4 \\
\hline $\operatorname{Lignin}^{7}$ & 23.5 & 27.7 & 22.2 & 27.5 & 25.2 \\
\hline $\mathrm{Ash}^{8}$ & 119.4 & 122.3 & 104.6 & 103.6 & 112.7 \\
\hline Total digestible nutrients ${ }^{9}$ & 727.1 & 717.8 & 736.5 & 709.8 & 722.0 \\
\hline
\end{tabular}

${ }^{1} \mathrm{Y}=163.65+2.0111 *$ Day $-0.0486 * \mathrm{Day}^{2}+0.0003017 * \mathrm{Day}^{3}\left(\mathrm{R}^{2}=0.56 ; \mathrm{CV}=6.47 \% ; \mathrm{P}=0.0179\right)$

${ }^{2} \mathrm{Y}=940.8917-3.6204 * \mathrm{Day}+0.0602 * \mathrm{Day}^{2}-0.0002807 * \mathrm{Day}^{3}\left(\mathrm{R}^{2}=0.46 ; \mathrm{CV}=1.08 \% ; \mathrm{P}=0.0053\right)$.

${ }^{3} \mathrm{Y}=165.4277+2.1803 *$ Day- $0.0199 *$ Day $^{2}\left(\mathrm{R}^{2}=0.44 ; \mathrm{CV}=14.23 \% ; \mathrm{P}=0.0005\right)$.

${ }^{4} \mathrm{Y}=367.6208+0.5698^{*}$ Day $\left(\mathrm{R}^{2}=0.27 ; \mathrm{CV}=7.33 \% ; \mathrm{P}=0.0002\right)$.

${ }^{5} \mathrm{Y}=201.2792+0.4633^{*}$ Day $\left(\mathrm{R}^{2}=0.33 ; \mathrm{CV}=9.01 \% ; \mathrm{P}<0.0001\right)$

${ }^{6} \mathrm{Y}=34.8636+0.7788^{*}$ Day-0.00064219* Day $^{2}\left(\mathrm{R}^{2}=0.63 ; \mathrm{CV}=9.71 \% ; \mathrm{P}<0.0001\right)$.

${ }^{7} \mathrm{Y}=-12.4333+2.1025 *$ Day-0.00339* Day $^{2}+0.00001633 * \mathrm{Day}^{3}\left(\mathrm{R}^{2}=0.30 ; \mathrm{CV}=15.93 \% ; \mathrm{P}=0.0002\right)$

${ }^{8} \mathrm{Y}=59.1083-3.6204 *$ Day $+0.0602 * \mathrm{Day}^{2}-0.0002807 * \mathrm{Day}^{3}\left(\mathrm{R}^{2}=0.46 ; \mathrm{CV}=8.49 \% ; \mathrm{P}=0.0053\right)$.

${ }^{9} \mathrm{Y}=829.7598-6.1384 *$ Day $+0.1026 *$ Day $^{2}-0.0005121 *$ Day $^{3}\left(R^{2}=0.17 ; C V=2.96 \% ; P=0.0212\right)$. 
Table 3 - Response of oat + rye grass grazing over grazing periods

\begin{tabular}{|c|c|c|c|c|c|}
\hline \multirow[b]{2}{*}{ Variable } & \multicolumn{4}{|c|}{ Period } & \multirow[b]{2}{*}{ Mean } \\
\hline & $\begin{array}{l}\text { July 5th - } \\
\text { August 1st }\end{array}$ & $\begin{array}{l}\text { August 2nd - } \\
\text { August 29th }\end{array}$ & $\begin{array}{l}\text { August 30th - } \\
\text { September 26th }\end{array}$ & $\begin{array}{l}\text { September 27th - } \\
\text { October 24th }\end{array}$ & \\
\hline Forage mass, $\mathrm{kg} / \mathrm{ha}$ & 1148.78 & 1248.69 & 1296.31 & 1335.10 & 1245.02 \\
\hline LBS, kg DM/100 kg LW ${ }^{1}$ & 4.00 & 5.17 & 4.24 & 3.11 & 4.17 \\
\hline Leaf/stem ratio ${ }^{2}$ & 1.12 & 1.96 & 1.72 & 0.72 & 1.27 \\
\hline Accumulation rate, $\mathrm{kg} \mathrm{DM} / \mathrm{ha} / \mathrm{day}^{3}$ & 44.58 & 39.21 & 44.02 & 65.01 & 48.63 \\
\hline Losses, $\mathrm{kg} / \mathrm{ha} /$ day $^{6}$ & 11.06 & 7.38 & 10.68 & 16.36 & 11.35 \\
\hline Losses, $\%$ LW/ha/day ${ }^{7}$ & 1.34 & 0.97 & 1.13 & 1.64 & 1.28 \\
\hline
\end{tabular}

LBS - leaf blade supply; AU - animal unit (450 kg).

${ }^{1} \mathrm{Y}=1.9399+0.09832 *$ Day- $0.00078967 * \mathrm{Day}^{2}\left(\mathrm{R}^{2}=0.41 ; \mathrm{CV}=21.73 \% ; \mathrm{P}<0.0001\right)$.

${ }^{2} \mathrm{Y}=-0.55563+0.07691^{*}$ Day-0.00058594* Day $^{2}\left(\mathrm{R}^{2}=0.72 ; \mathrm{CV}=22.52 \% ; \mathrm{P}<0.0001\right)$.

${ }^{3} \mathrm{Y}=62.81857-0.87086 *$ Day+0.00794* Day $^{2}\left(\mathrm{R}^{2}=0.37 ; \mathrm{CV}=27.08 \% ; \mathrm{P}=0.0023\right)$.

${ }^{4} \mathrm{Y}=979.10718-6.79126^{*} \mathrm{Day}+0.06493^{*} \mathrm{Day}^{2}\left(\mathrm{R}^{2}=0.30 ; \mathrm{CV}=16.00 \% ; \mathrm{P}=0.0178\right)$.

${ }^{5} \mathrm{Y}=2.17562-0.01510 *$ Day $+0.0001444 * \mathrm{Day}^{2}\left(\mathrm{R}^{2}=0.30 ; \mathrm{CV}=16.00 \% ; \mathrm{P}=0.0178\right)$.

${ }^{6} \mathrm{Y}=18.51883-0.35888 *$ Day $+0.00305 * \mathrm{Day}^{2}\left(\mathrm{R}^{2}=0.32 ; \mathrm{CV}=42.35 \% ; \mathrm{P}=0.0014\right)$.

${ }^{7} \mathrm{Y}=2.08069-0.03462 *$ Day+0.00027473 $* \mathrm{Day}^{2}\left(\mathrm{R}^{2}=0.15 ; \mathrm{CV}=46.84 \% ; \mathrm{P}=0.0175\right)$.

Although forage mass did not vary, the supply of leaf blades had more participation in pasture intermediate periods at the same time when there was a more significant contribution of rye grass leaves, with a high correlation $(\mathrm{r}=0.66 ; \mathrm{P}<0.0001)$ between the two variables. This difference, which was caused by pasture structure, is also found in the last period, when participation of stem mass of rye grass increases due to the reproductive stage of the species in this period, making accumulation rate $\mathrm{kg} / \mathrm{day} /$ ha/DM more expressive at this moment. As forage mass was kept the same in all periods (Table 3), the supporting capacity of the animal supported by grazing ranged according to accumulation rate in $\mathrm{kg} / \mathrm{day} / \mathrm{ha} / \mathrm{DM}$, with the lowest load found in the second period $(759.80 \mathrm{~kg} / \mathrm{ha})$ and the heaviest one found in the last period $(1018.80 \mathrm{~kg} / \mathrm{ha})$. If the observed mean, $885.92 \mathrm{~kg} / \mathrm{ha}$, is taken into account, stocking rate was around $2 \mathrm{AU} / \mathrm{ha}$, but since yearling heifers were used, if the objective was to reach $65 \%$ of the adult weight for mating, this would make it possible to manage $3 \mathrm{AU} / \mathrm{ha}$, maximizing gain per grazing area.

It was found that forage losses expressed in absolute values, $\mathrm{kg} / \mathrm{ha} /$ day and in $\%$ of LW (Table 3) presented a quadratic behavior as the supporting capacity of the animal increased, the losses in $\mathrm{kg} / \mathrm{ha} /$ day also increased, presenting a correlation of $0.40(\mathrm{P}=0.0058)$. According to Hillesheim (1998), trampling, difficulty of apprehension and natural senescence of the plants determine forage losses, where the supporting capacity of the animal and forage mass are one of the main variables determining the intensity of the losses. The same quadratic behavior for losses in \%LW and in $\mathrm{kg} / \mathrm{ha}$ /day was obtained by Rocha et al. (2004), during the months of evaluation, with a reduction in the losses during August and with greater losses as the grazing period reached the final stage.

Both the composition of the harvested forage (Table 2) and the forage supply (Table 3) during the grazing period did not limit pasture intake, which increased linearly over days of pasture use with an increase of $0.165 \mathrm{~g}$ /day (Figure 2).

According to Forbes (1995), animal voluntary intake is controlled by more than one factor, and in high palatability diets, total dry matter intake may increase as a consequence of animal performance (Russek, 1978). Because factors which may limit this linear increase in dry matter intake are not detected and because animals presented a constant evolution of live weight, it is likely that this increase occurred to supply the energy required for maintenance and

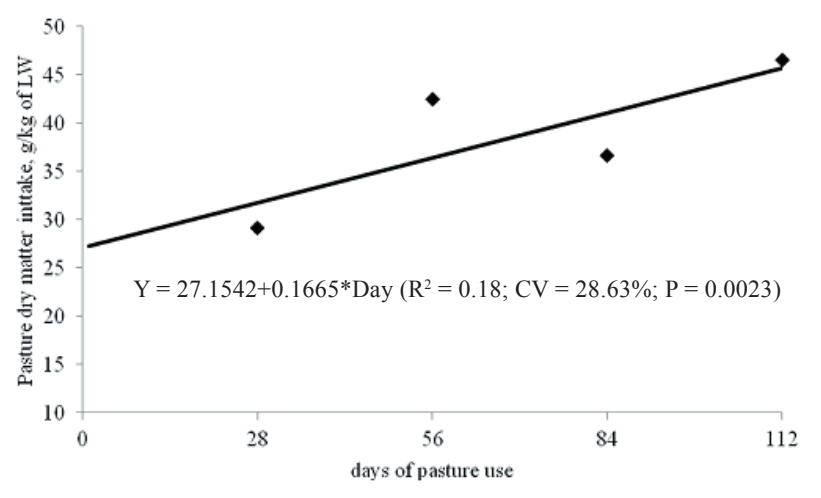

LW - live weight; CV - coefficient of variation.

Figure 2 - Variation in pasture intake in percentage of live weight during periods of oat + rye grass pasture use. 
gain. However, it is important to stress that from the second period on, pasture DM intake was over $30 \mathrm{~g} / \mathrm{kg}$ of live weight at the same time when there was an increase in the occurrence of dead material on pastures, so it can be inferred that determination of intake by the agronomic method may have overestimated intake as pasture cycle advances.

Forage mass did not differ significantly between treatments (Table 4), and all of them were within the range from 1200 to $1600 \mathrm{~kg} \mathrm{DM} / \mathrm{ha}$, which Mott (1984) considers as necessary for the maximum animal performance in temperate pastures.

Forage supply, in $\mathrm{kg}$ of DM/100 kg LW, was higher for the NS treatment, and the MEG and BRM treatments were intermediate; the lowest supply was found for BRM + MEG. Although there were differences between the supplies, there was no limitation for animal performance, once the lowest supply found was $9.76 \mathrm{~kg} \mathrm{DM} / 100 \mathrm{~kg}$ LW and for intake to be unlimited, forage supply should always be higher than 4 to $6 \mathrm{~kg} / 100 \mathrm{~kg}$ of LW (Mott, 1984). According to Bandinelli et al. (2005), real supply of average biomass higher than $5.74 \mathrm{~kg}$ of DM/100 kg of LW allows individual gains higher than $1 \mathrm{~kg} / \mathrm{day}$. When grazing is managed with daily supply from 10 to $12 \mathrm{~kg}$ of DM/ $100 \mathrm{~kg}$ of $\mathrm{LW}$, the maximum animal performance can be demonstrated (Hodgson, 1990), so heifers of all treatments had the opportunity to show their maximum potential of individual performance due to the supplies and per area, because the forage mass to which they were subjected was $1245.02 \mathrm{~kg} \mathrm{DM} / \mathrm{ha}$ (Table 3) on average. Regarding the supply of leaf blades, in which, according to Forbes \& Hodgson (1985), of the components of the forage, leaf fraction is the one which presents the best quality and represents more than $80 \%$ of the diet, there was no difference between treatments $(\mathrm{P}>0.05)$ (Table 4).
No significant difference was found for the leaf/stem ratio in function of the type of supplement supplied, corroborating the results found by Freitas et al. (2005b), when increasing, decreasing and fixed levels of supplement were offered to heifers on oat + rye grass pastures. This shows that response of pasture for structural components such as leaves and stems is not affected by the different types of supplements offered to heifers. Animal supporting capacity did not differ $(\mathrm{P}>0.05)$ between treatments even when supplement was offered to the heifers. For the MEG treatment, it was expected that the supporting capacity of the animal would not increase due to the reduced amount supplement provided, which corresponded to $3 \%$ over the total dry matter intake stipulated at 3\%. Pasture intake was reduced, but not in a significant manner among treatments, for treatments BRM and BRM + MEG with a greater inclusion of concentrate, $8 \mathrm{~g} / \mathrm{kg}$ of LW. Because pasture intake did not differ between treatments, despite the reduction by $3.83 \%$ and $12.5 \%$ in treatments $\mathrm{BRM}$ and $\mathrm{BRM}$ + MEG in relation to the treatment without supplementation, and because there was no difference in daily accumulation rate $\mathrm{kg} / \mathrm{DM} / \mathrm{ha} /$ day of pasture (Table 4 ), supporting capacity of the animals was not influenced by treatments $(\mathrm{P}>0.05)$. Supplement type may be one of the determining factors for the increase in supporting capacity of the animal. For supplements such as soybean or corn hulls with a supply of $9 \mathrm{~g} / \mathrm{kg}$ of $\mathrm{LW}$, the supporting capacity of the animal was incremented only with the use of corn $(977.6 \mathrm{~kg} / \mathrm{ha})$, not differing between soybean hull and exclusive grazing: 923.7 and $877.0 \mathrm{~kg} / \mathrm{ha}$, respectively (Santos et al., 2004). When increasing or decreasing (3; 6; $9 ; 12 ; 15 \mathrm{~g} / 100 \mathrm{~kg}$ of LW) supplements of wheat meal or fixed value of $9 \mathrm{~g} / \mathrm{kg}$ of LW were used during the grazing period, the supporting capacity of the animal was not changed, with an average of $1,961.0 \mathrm{~kg} / \mathrm{ha}$ of live weight (Freitas et al., 2005b).

Table 4 - Response of oat + rye grass grazing subjected to grazing by beef heifers supplemented with different energy sources

\begin{tabular}{|c|c|c|c|c|c|}
\hline \multirow{2}{*}{ Variable } & \multicolumn{4}{|c|}{ Supplement types } & \multirow{2}{*}{ SE } \\
\hline & NS & MEG & BRM & $\mathrm{BRM}+\mathrm{MEG}$ & \\
\hline Forage mass, kg DM/ha & 1399.86 & 1189.50 & 1233.61 & 1202.93 & 73.41 \\
\hline $\mathrm{FS}, \mathrm{kg} \mathrm{DM} / 100 \mathrm{~kg} \mathrm{LW}$ & $11.44 \mathrm{a}$ & $10.72 b$ & $10.45 b$ & $9.76 \mathrm{c}$ & 0.21 \\
\hline FS leaf blades, $\mathrm{kg} \mathrm{DM} / 100 \mathrm{~kg} \mathrm{LW}$ & 4.39 & 4.27 & 4.00 & 3.88 & 0.17 \\
\hline Leaf/stem ratio & 1.30 & 1.46 & 1.31 & 1.46 & 0.11 \\
\hline Accumulation rate, $\mathrm{kg} \mathrm{DM} / \mathrm{ha} /$ day & 46.57 & 48.11 & 48.73 & 49.41 & 5.84 \\
\hline Supporting capacity, $\mathrm{kg} / \mathrm{ha}$ & 894.02 & 858.80 & 883.41 & 944.06 & 42.46 \\
\hline Stocking rate, $\mathrm{AU} / \mathrm{ha}$ & 1.99 & 1.91 & 1.96 & 2.10 & 0.09 \\
\hline Losses, $\mathrm{kg} / \mathrm{ha} /$ day & 10.30 & 11.16 & 11.01 & 13.01 & 1.13 \\
\hline Losses, \% LW/ha/day & 1.14 & 1.25 & 1.26 & 1.43 & 0.17 \\
\hline Pasture dry matter intake, $\mathrm{g} / \mathrm{kg}$ of $\mathrm{LW}$ & 39.18 & 40.69 & 37.74 & 34.27 & 0.28 \\
\hline
\end{tabular}

Means followed by different letters in the row differ $(\mathrm{P}<0.05)$ by the $\mathrm{t}$ test.

Animal unit - 450 kg; SE - standard error; NS - no supplementation; MEG - Megalac; BRM - brown rice meal; BRM+MEG - brown rice meal + Megalac. 


\section{Conclusions}

Supplementation of beef heifers with brown rice meal and/or protected fat does not reflect in changes in the production parameters of oat + rye grass grazing or change pasture intake.

\section{Acknowledgments}

The authors would like to thank Química Geral do Nordeste for suplying Megalac ${ }^{\circledR}$ so this experiment could be carried out.

\section{References}

ASSOCIATION OF OFFICIAL ANALYTICAL CHEMISTRY - AOAC. Official methods of analysis. 16.ed. Washington, D.C. 1995. 2000p.

BAIER, C.A.; FLOSS, E.L.; AUDE, M.I.S. As lavouras de inverno-1. Aveia, triticale, centeio, colza e alpiste. 2.ed. São Paulo: Editora Globo, 1989. 172p.

BANDINELLI, D.G.; QUADROS, F.L.F.; MAIXNER, A.R. et al. Desempenho animal em pasto de aveia e azevém com distintas biomassas de lâminas foliares. Pesquisa Agropecuária Brasileira, v.40, n.12, p.1231-1238, 2005.

CAMPBELL, A.G. Grazed pasture parameters. Pasture dry matter production and availability in a stocking rate and grazing management experiment with dairy cow. Journal of Agricultural Science, v.67, n.2, p.199-210, 1966.

EMPRESA BRASILEIRA DE PESQUISA AGROPECUÁRIA EMBRAPA. Centro Nacional de Pesquisa de Solos. Sistema brasileiro de classificação de solos. Brasília: EMBRAPA; Rio de Janeiro, 1999. $412 \mathrm{p}$.

EUCLIDES, V.P.B.; MACEDO, M.C.M.; OLIVEIRA, M.P. Avaliação de diferentes métodos de amostragem sob pastejo. Revista Brasileira de Zootecnia, v.21, n.4, p.691-702, 1992.

FREITAS, F.K.; ROCHA, M.G.; BRONDANI, I.L. Suplementação energética na recria de fêmeas de corte em pastagem cultivada de inverno. Dinâmica da pastagem. Revista Brasileira de Zootecnia, v.34, n.6, p.2029-2038, 2005a.

FREITAS, F.K.; ROCHA, M.G.; RESTLE, J. et al. Suplementação energética na recria de fêmeas de corte em pastagem cultivada de inverno. Produção animal. Revista Brasileira de Zootecnia, v.34, n.4, p.1256-1266, 2005b.

FRIZZO, A.; ROCHA, M.G.; RESTLE, J. et al. Produção de forragem e retorno econômico da pastagem de aveia e azevém sob pastejo com bezerras de corte submetidas a níveis de suplementação energética. Revista Brasileira de Zootecnia, v.32, n.3, p.632-642, 2003.

FONSECA, M. Plantio direto de forrageiras: sistema de produção. Guaíba: Editora Agropecuária, 1997. 101p.

FORBES, J.M. Voluntary intake and diet selection in farm animals. Wallingford: CAB Publishing, 1995. 544p.

FORBES, T.D.A.; HODGSON, J. Comparative studies of the influence of sward conditions on the ingestive behaviour of cows and sheep. Grass and Forage Science, v.40, p.69-77, 1985.

FUNSTON, R. N. Fat supplementation and reproduction in beef females. Journal of Animal Science, v.82, p.154-161, 2004. (E. Suppl.).

HILLESHEIM, A. Fatores que afetam o consumo e perdas de capim elefante (Pennisetum purpureum SCHUM.) sob pastejo. 1987. $94 \mathrm{f}$. Dissertação (Mestrado em Agronomia) - Escola Superior de Agricultura "Luiz de Queiroz"/Universidade de São Paulo, São Paulo.

HILLESHEIM, A. Manejo do gênero Pennisetum sob pastejo. In: SIMPÓSIO SOBRE MANEJO DE PASTAGEM, 9., 1998, Piracicaba. Anais... Piracicaba: Fundação de Estudos Agronômicos "Luiz de Queiroz", 1998.
HODGSON, J. Grazing management. Science into practice. England: Longman Scientific \& Technical, 1990. 203p.

KLINGMANN, D.L.; MILES, S.R.; MOTT, G.O. The cage method for determining consumption and yield of pasture herbage. Journal of Society Agronomy, v.35, p.739-746, 1943.

LICITRA, G.; HERNANDEZ, T.M.; VAN SOEST, P.J. Standardization of procedures for nitrogen fractionation of ruminant feeds. Animal Feed Science and Technology, v.57, p.347-358, 1996.

MORAES, A. Produtividade animal e dinâmica de uma pastagem de pangola (Digitaria decumbens Stent), azevém (Lolium multiflorum Lam.) e trevo branco (Trifolium repens L.) submetida a diferentes pressões de pastejo. 1991. 200f. Tese (Doutorado em Zootecnia) - Universidade Federal do Rio Grande do Sul, Porto Alegre.

MORENO, J.A. Clima do Rio Grande do Sul. Porto Alegre: Secretaria da Agricultura, 1961. 41p.

MOTT, G.O.; LUCAS, H.L. The design conduct and interpretation of grazing trials on cultivated and improved pastures. In: INTERNATIONAL GRASSLAND CONGRESS, 6., 1952, Pennsylvania. Proceedings... Pennsylvania: State College Press, 1952. p.1380-1395.

MOTT, G.O. Relationship of available forage and animal performance in tropical grazing systems. In: FORRAGE GRASSLAND CONFERENCE, 1984, Houston, Texas. Proceedings... Lexington: American Forage and Grassland Council, 1984. p.373-377.

NATIONAL RESEARCH COUNCIL - NRC. Nutrient requirements of beef cattle. 7.ed. Washington D.C.: 1996. 244p.

PILAU, A.; ROCHA, M.; RESTLE, J. et al. Recria de novilhas de corte com diferentes níveis de suplementação energética em pastagem de aveia preta e azevém. Revista Brasileira de Zootecnia, v.33, n.6, p.2104-2113, 2004

PILAU, A.; ROCHA, M.G.; RESTLE, J. et al. Desenvolvimento de novilhas de corte recebendo ou não suplementação energética em pastagem com diferentes disponibilidades de forragem. Revista Brasileira de Zootecnia, v.34, n.5, p.1483-1492, 2005a.

PILAU, A.; ROCHA, M.G.; RESTLE, J. et al. Produção de forragem e produção animal em pastagem com duas disponibilidades de forragem associadas ou não à suplementação energética. Revista Brasileira de Zootecnia, v.34, n.4, p.1130-1137, 2005b.

PÖTTER, L. Uso de suplementos em pastagem cultivada de inverno para bezerras de corte. 2008. 128f. Tese (Doutorado em Zootecnia) Universidade Federal de Santa Maria, Santa Maria.

ROCHA, M.G.; MONTAGNER, D.B.; SANTOS, D.T. et al. Parâmetros produtivos de uma pastagem temperada submetida a alternativas de utilização. Revista Brasileira de Zootecnia, v.33, n.6, p.1386-1395, 2004.

RODRIGUES, R.C.; COELHO, R.W.; REIS, J.C.L. Rendimento de forragem e composição química de cinco gramíneas de estação fria. Pelotas: EMBRAPA Clima Temperado, 2002. 3p. (Comunicado Técnico, 77)

ROSO, C.; RESTLE, J.; SOARES, A.B. et al. Produção e qualidade de forragem da mistura de gramíneas anuais de estação fria sob pastejo contínuo. Revista Brasileira de Zootecnia, v.28, n.3, p.459-467, 1999.

ROSO, C.; RESTLE, J.; SOARES, A.B. et al. Aveia preta, triticale e centeio em mistura com azevém. 1. Dinâmica, produção e qualidade de forragem. Revista Brasileira de Zootecnia, v.29, n.1, p.75-84, 2000.

RUSSEK, M. Semi-quantitative simulation of food intake control and weiht regulation. In: BOOTH, D.A. (Ed.) Hunger models. Computable theory of the feeding control. New York: Academic Press, 1978. p.195-226.

SANTOS, D.T.; ROCHA, M.G.; GENRO, T.C.M. et al. Suplementos energéticos para recria de novilhas de corte em pastagens anuais. Análise econômica. Revista Brasileira de Zootecnia, v.33, n.6, p.2359-2368, 2004 (supl. 3).

SILVEIRA, M.F.; KOZLOSKI, G.V.; BRONDANI, I.L. et al. Ganho de peso vivo e fermentação ruminal em novilhos mantidos em pastagem cultivada de clima temperado e recebendo diferentes suplementos. Ciência Rural, v.36, n.3, p.898-903, 2006. 
TAIZ, L.; ZEIGER, E. Fisiologia vegetal. 4.ed. Porto Alegre: Editora Artimed, 2009. 719p.

VAN SOEST, P.J.; ROBERTSON, J.B.; LEWIS, B.A. Methods for dietary fiber, neutral detergent fiber, and nonstarch polysaccharides in relation to animal nutrition. Journal of Dairy Science, v.74, p.3583-3597, 1991.
WEISS, W.P.; CONRAD, H.R.; ST. PIERRE, N.R. A theoretically-based model for predicting total digestible nutrient values of forages and concentrates. Animal Feed Science and Technology, v.39, p.95-110, 1992.

WILM, H.G.; COSTELLO, D.F.; KLIPPLE, G.E. Estimating foragem yield by the double-sampling methods. Journal of American Society of Agronomy, v.36, p.194-203, 1944. 